\title{
Identifying and categorizing cobenefits in state-supported Australian indigenous environmental management programs: international research implications
}

\author{
Marcus Barber ${ }^{1}$ and Sue Jackson ${ }^{2,3}$
}

\begin{abstract}
Significant natural resource management investment is flowing to bioculturally diverse areas occupied by indigenous and other socioeconomically and politically marginalized groups. Such investment focuses on environmental benefit but may also generate ancillary economic, social, and other cobenefits. Increased investor interest in such cobenefits is driving the emerging research literature on cobenefit identification, categorization, and assessment. For local people undertaking community-based natural resource management, this emerging cobenefit discourse creates opportunities for more holistic program assessments that better reflect local perspectives, but it also contains risks of increased reporting burdens and institutional capture. Here, we synthesize and critically review the cobenefit literature arising from Australian indigenous cultural and natural resource management programs, a context in which there is a strong investor interest in cobenefits, particularly from government. We identify a wide suite of cobenefits in the existing literature and highlight previously unrecognized conceptual gaps and elisions in cobenefit categorization, including inconsistencies in category definition, the underanalysis of key categories, and a lack of systematic attention to beneficiaries as well as benefits. We propose a clarified and expanded conceptual framework to identify consistently the full suite of benefits, thereby enabling further assessment, valuation, and development of incentive mechanisms, standards, and guidelines. Our analysis has implications for community-based natural resource management assessment in a wide range of international contexts.
\end{abstract}

Key Words: community-based natural resource management, conservation governance, market-based conservation, payments for ecosystem services, sustainable development

\section{INTRODUCTION}

The debate about the social effects of conservation has shifted significantly since the late 1980s. Sustained criticism of the "fortress" model of conservation, which locked local communities out of environmental management decisions, has compelled the development of more socially responsible approaches (Salafsky and Wollenberg 2000, Adams and Mulligan 2003). Protected areas are now more frequently managed for multiple objectives that include indigenous and local livelihoods, biodiversity conservation, sustainable resource use, and poverty alleviation (Borrini-Feyerabend et al. 2004, Stevens 2014).

Conservation interest has also widened geographically, expanding from formal nature reserves to include territories under the wider control and management of indigenous peoples. Such peoples may also have rights in emerging tradable ecological commodities and environmental services such as carbon sequestration and watershed protection. Payment for ecosystem services (PES) and other financial incentives may enable integrated conservation and development goals, addressing the lack of investment in conservation management, particularly on privately and communally held land (Pattanayak et al. 2010, Vatn 2010). The linkages between anthropogenic climate change and sustainable development programs are currently the most prominent in global conservation discourse (Watts et al. 2015). However, the debate now encompasses the entire relationship between biodiversity and human welfare (Adams and Hutton 2007), especially the compatibility of conservation and poverty alleviation (Holmes and Cavanagh 2016).
Increased investment in local and indigenous cultural and natural resource management (ICNRM) and indigenous PES has generated corresponding interest in the full range of benefits accruing from such investment. This interest partly derives from the broader trend toward neoliberal performance-based management and toward expanded public and private sector reporting and accountability requirements (Jackson 2013, Pugalis 2013, Holmes and Cavanagh 2016). However, it also derives from the desire to target scarce resources more effectively, to attract a premium price for exchange, and to highlight environmental policy measures that generate health and other benefits (Kollmuss et al. 2008, Netbalance Foundation 2013, Watts et al. 2015).

Despite this growing interest, a recent high-profile global call for "compelling arguments for action that emphasizes cobenefits" in mitigating anthropogenic climate change (Watts et al. 2015:29) does not refer to a research agenda for identifying, validating, or measuring these benefits. The beneficial socioeconomic effects of community-based natural resource management activities, either indigenous or nonindigenous, remain understudied (Hibbard and Lurie 2012), and there appear to be no agreed-upon metrics or even broadly accepted approaches for assessing the effectiveness of new community-based environmental institutions (Sutter and Parreño 2007, Hibbard and Lurie 2012). Challenges for major international initiatives in consistently delivering sustainability benefits (Olsen 2007, Kollmuss et al. 2008) indicate that reducing uncertainty and complexity in the identification, evaluation, and monitoring of cobenefits is a research priority.

${ }^{1}$ CSIRO, ${ }^{2}$ Australian Rivers Institute, Griffith University, ${ }^{3}$ School of Geography, University of Melbourne 
The Australian context both reflects and presages these ongoing international trends. Australia is a useful case to review because there has been particular investor and participant interest in the broad social, cultural, and health consequences of ICNRM as well as in the economic and environmental consequences, encouraging additional empirical and analytical clarity in cobenefit observation and demarcation. Such interest arises from: (1) substantially increased public funding for ICNRM since the late 1980s (Hill et al. 2013); (2) national efforts to redress indigenous socioeconomic and health disadvantages; (3) a rapidly growing indigenous estate; (4) indigenous desires for recognition of their cultural and custodial role over Australian landscapes; (5) the presence of a social security system that mitigates some economic impacts of ICNRM, augmenting the profile of other cobenefits; and (6) indigenous participation in PES, particularly market-based emissions reduction and carbon sequestration projects.

Our synthesis of the Australian literature identifies key reported cobenefits but, equally importantly, addresses key conceptual and definitional strengths and weaknesses through which those benefits have been reported or elided. In doing so, it contributes to broader international discussions of cobenefit identification, classification, and assessment. We focus our attention on the formal ICNRM sector, noting that the conflation of formalised ICNRM with wider ongoing indigenous customary management activity remains an ongoing risk (Altman and Kerins 2012, Jackson and Palmer 2015). Before turning specifically to the results of the cobenefit analysis, we provide some further background context to Australian ICNRM.

\section{Australian indigenous cultural and natural resource management} The importance of landscapes to indigenous Australians has been the subject of considerable research (Williams 1986, Myers 1991, Morphy 1995, Strang 1997, Rose 2000, Weir 2009, Bradley 2010, Gammage 2011). Land restitution initiatives have resulted in $22 \%$ of the Australian continent being under indigenous tenure, with nonexclusive shared title over a further 10\% (Altman and Jackson 2014). Much of that tenure is in regional and remote areas that remain in better ecological condition than heavily settled areas, albeit they are still degraded from land use changes and altered customary management regimes that followed British colonization. National surveys of indigenous people demonstrate strong commitment to the maintenance of their land, languages, institutions of management, and cultural heritage (Biddle and Swee 2012).

Australian ICNRM initiatives have grown in response to demands for indigenous recognition, natural and cultural resource rights, and regional development (Young et al. 1991, Baker et al. 2001, Smyth 2011, Bauman et al. 2013, Hill et al. 2013, Altman and Jackson 2014). Indigenous people wish to derive income and finance the retention and reestablishment of traditional land management practices (Campbell et al. 2007, Luckert et al. 2007, Putnis et al. 2007, Muller 2008, Altman and Kerins 2012, Winer et al. 2012). This burgeoning movement now encompasses several hundred community-based indigenous land management groups around Australia, undertaking activities as diverse as: greenhouse gas emissions reduction and carbon sequestration, vulnerable and pest species management, natural resource harvesting, and cultural heritage protection. Local cultural management priorities are combined with wider aspirations for community, economic, social, and environmental development (Davies et al. 2013, Kerins 2013).

ICNRM activity appears to have considerable public support (Zander and Garnett 2011, Zander 2013), but the social aspects or benefits do not yet figure prominently in assessments (Zander 2013). Indigenous perceptions of ICNRM appear to be strongly positive (Sithole et al. 2008, Altman and Kerins 2012), but national surveys of those perceptions are yet to be undertaken (Biddle and Swee 2012). The popularity of the ICNRM sector among indigenous people has meant that demand for state support has substantially outstripped supply. Stimulating "willingness to pay" and validating calls for increased funding, including from the private sector, is therefore a major sectoral priority. However, attempting to demonstrate the wider nonenvironmental benefits from environmental services is a strategy that appeals to dominant instrumental values and costbenefit logics (Jackson and Palmer 2015, Holmes and Cavanagh 2016); therefore, local people undertake it at some risk of additional reporting burdens and bureaucratic capture (Nadasdy 2003, Agrawal 2005, McAfee and Shapiro 2010, Altman and Kerins 2012, Fache 2014). At a broader level, ICNRM is also increasingly important to the ongoing public debate about the future of small and remote indigenous communities (Scrimgeour 2007).

\section{METHODS}

\section{Context and approach}

Our synthesis of research was generated through an iterative process of research (Petticrew and Roberts 2006) undertaken over a four-year period. The duration and iteration of this synthesis was intentional and was a methodological response to three contextual conditions. The first condition was that crucial material was only available as grey literature, beyond the remit of electronic databases and major search engines. The second condition was that there was significant variation in the terms used, the meanings assigned to the same terms across different papers, and the disciplinary and publishing orientations of authors. This meant that standard keyword searches were ineffective or inefficient (Petticrew and Roberts 2006) because relevant documents (Maller et al. 2008) were not locatable without further investigation and cross-referencing of article content, article reference lists, and adjacent research, nonpeer-reviewed literature, and online resources. The third condition was that the emerging nature of this field and a recent surge in cobenefit research project applications in Australia meant that new literature with the characteristics of the first and second conditions was emerging throughout the research process.

\section{Literature identification}

The duration and iteration of our research over phases enabled the identification of low-profile, rare, diversely defined, and recently released material central to the research goals. The first phase took place in 2012 and involved an initial survey that summarized cobenefits reported in extant literature relating to Australian ICNRM and PES carbon abatement activities. Of particular significance to this effort were past reviews (Ganesharajah 2009, Davies et al. 2010, 2011, Weir et al. 2011), the majority of which were partial or had not been generated for 
international peer-reviewed journals. In the second phase, references cited in these previous reviews were located, and citations within those references were examined for additional earlier sources. This activity was supported by searches of two online databases (Scopus, Web of Knowledge) for the combination of key words "cobenefit" and "Australia," limited to social sciences subject areas. These listings were manually screened for relevance to the topic, and papers that focused on environmental cobenefits such as biodiversity conservation were excluded. Further updates of the peer-reviewed journal literature were undertaken during manuscript production (2015) and revision (2016) and were augmented by further literature located through the authors' professional networks.

\section{Cobenefit categorization}

The initial literature identification and analysis phase highlighted that categorizations drawn from existing reviews were incomplete. What was needed was not just a synthesis of reported Australian ICNRM cobenefits on an empirical level, but also a critical analysis of the way that such cobenefits were being reported and categorized on a definitional and conceptual level. As a result, the variability and elisions in conceptual categorization became an important emphasis of the analytical work in the subsequent synthesis. This work was iterative, informed by newly sourced literature and by related fieldwork by the lead author reported elsewhere (Barber 2015a,b). Identifying and addressing key issues through refining terminology, adding categories, and clarifying recipients then improved the framework developed herein for organizing and categorizing the cobenefits reported in existing studies.

\section{RESULTS}

The results section is divided into two major parts. We first critically analyze the conceptual and definitional issues in the identification and reporting of Australian ICNRM cobenefits. Our clarifications include an overarching term used to describe such secondary effects of environmentally focused action, a revised framework for cobenefit subcategorization and definition, and the demarcation of beneficiaries. We then use our conceptual clarifications to reanalyze and synthesize the diverse Australian evidence for ICNRM cobenefits.

\section{Conceptual analysis}

\section{Cobenefit terminology}

Research on the nonenvironmental effects of Australian ICNRM has adopted different terms to describe those effects. The two most common are the positively defined term "benefit" or "cobenefit" (Ganesharajah 2009, Weir et al. 2011, Pew Charitable Trusts 2015) and the neutrally defined term "outcome" (Allen Consulting Group 2011, Davies et al. 2011, Urbis 2012). Investigating the potential consequences of using different terms in analyzing ICNRM effects is beyond the scope of this paper, but it is important to note these variations in terminology and that they can be extrapolated into a series of positively, neutrally, or negatively framed terms (Table 1). This extrapolation, and the associated discussion, does not appear previously in the literature we located for our study, but clearly, such framings can influence how research is oriented and conducted, and therefore, the results it generates.
Table 1. Potential terminology for the effects of environmental programs.

\begin{tabular}{ll}
\hline \hline Connotation of the term & Term \\
\hline Positive & Benefit, improvement, advantage, good \\
Neutral & Outcome, effect, impact, consequence \\
Negative & $\begin{array}{l}\text { Disbenefit, deterioration, disadvantage, } \\
\text { bad }\end{array}$ \\
\hline
\end{tabular}

Here, we use the term cobenefits, consistent with contemporary international discussions. This can minimize or elide analytical consideration of negative outcomes, but our primary conceptual goal is to examine and extend the categories currently used to classify effects and those affected in the existing literature. These categorizations function appropriately as lenses for effect identification, regardless of whether the effects themselves are framed positively (cobenefit), neutrally (outcome), or negatively (disbenefit). The way in which effects are framed may assume greater importance in the stages beyond this primary identification stage, i.e., in the stages of assessment, measurement, and evaluation. These are the stages in which the net effect, i.e., the combination of the positive and negative effects of ICNRM within a particular effect category, may be an important empirical question to resolve. The overarching terminology used may implicitly encourage or hinder the identification of positive and negative effects, so further consideration of which term is appropriate may be warranted in studies emphasizing valuation rather than identification.

\section{Cobenefit subcategorization}

Definitional clarity and characterization of benefit types has been nominated as a key requirement for better project certification in Australian natural resource management (Netbalance Foundation 2013). In practice, the identification of cobenefits (and of beneficiaries) is an iterative process. Predetermined categories and classifications can and should aid the identification of cobenefits, and the identification of cobenefits can also suggest new forms of classification. Categories necessarily intersect and overlap. In indigenous contexts, where holism is a key principle, greater emphasis is often placed on such overlaps and on the interrelationships between outcomes (Weir et al. 2011, Urbis 2012). This potential for combined or compounded benefits further emphasizes the need for clarity and rigor in attributing benefits to avoid "double counting." Facilitating wider understanding of ICNRM cobenefits increases the chances of program alignment with indigenous perspectives but also raises issues of demarcation and definition in formal cobenefit categorization and assessment.

The cobenefit categorizations adopted in the Australian ICNRM literature reflect this tension between holism and specificity. In some cases, terms such as "well-being" have been defined to accommodate indigenous perspectives and so are inclusive of a wide array of social, cultural, and economic outcomes (Greiner et al. 2007, Pew Charitable Trusts 2015). In other cases, benefits identified by respective studies as "social" or "cultural," for example, self-esteem, hope, identity, and self-worth (Sithole et al. 2008, Kingsley et al. 2009a,b), have also been understood in terms of individual psychology or, indeed, through such compound 
terms as "psycho-social" (Morice 1976, Campbell et al. 2008, Green and Martin 2016). In general, studies variously refer to these kinds of benefits as social and/or cultural, at times in the context of group and community well-being (Greiner et al. 2007, Ganesharajah 2009, Davies et al. 2010, Weir et al. 2011, Urbis 2012, Pew Charitable Trusts 2015). Social benefits and well-being can be broadly and inclusively defined to contrast with "economic" benefits (Urbis 2012, Pew Charitable Trusts 2015); research identifying "political" benefits as a separate category appears to be underdeveloped. The health and economic cobenefit categories are the most consistently defined across multiple studies, but considerable variations exist in terminology and emphasis.

Cross-referencing and comparing existing categorizations in the literature also highlights that classification frameworks are not provided consistently, and the key terms used to classify cobenefits are often undefined. In addition, no one study contained all the cobenefit subcategories we identified. Our analysis produced a revised framework (Table 2) for cobenefit identification that clarifies and combines existing categories of benefit that are found across existing ICNRM studies but are not fully defined or conceptually demarcated by any one study. The framework also provides definitions for each category, generating both consistency and comprehensiveness for consideration and demarcation of ICNRM cobenefits. The framework (Table 2) effectively represents a novel synthesis in Australian ICNRM cobenefit analysis.

Table 2. Cobenefit category framework.

\begin{tabular}{ll}
\hline \hline $\begin{array}{l}\text { Cobenefit } \\
\text { category }\end{array}$ & Definition \\
\hline $\begin{array}{l}\text { Health and } \\
\text { well-being } \\
\text { Social }\end{array}$ & $\begin{array}{l}\text { Pertaining to biophysical, psychological, and } \\
\text { collective aspects } \\
\text { Pertaining to institutional and organizational roles } \\
\text { and relationships, and to networks, patterns, and } \\
\text { systems of human organization }\end{array}$ \\
Cultural & $\begin{array}{l}\text { Pertaining to learned ideas, beliefs, values, knowledge, } \\
\text { behaviours, etc. that demarcate group identities and } \\
\text { constitute shared bases of social action }\end{array}$ \\
& $\begin{array}{l}\text { Pertaining to systems of governance and the exercise } \\
\text { of authority }\end{array}$ \\
Political & Pertaining to material resources and conditions \\
\hline
\end{tabular}

\section{Cobenefit beneficiary identification}

Demonstrating the wider value of ICNRM initiatives requires not just the systematic identification of benefits, but also of beneficiaries. However, this step generally has received insufficient attention in the existing Australian ICNRM literature. As with the categories of benefit, categories of beneficiary can overlap. ICNRM activity may variously involve: direction or supervision by elders, engagement with local indigenous communities as a whole, collaboration with nonlocal or nonindigenous agencies, partnering or networking with other ICNRM agencies, and communication with the wider national public. This makes clarity in the definition of ICNRM beneficiaries, in sectoral, demographic, and geographic terms, of some importance.

In the existing cobenefits literature, there is a prevalent focus on local indigenous beneficiaries. This focus is often implicit or at least less than fully articulated. Within this category, distinctions have been drawn in terms of the ICNRM program and its direct participants, the family, the indigenous landowning group, and the local indigenous community as a whole (Sithole et al. 2008, Urbis 2012). The use of terms such as "communities" (Sithole et al. 2008, Urbis 2012) can enable slippages between indigenous and nonindigenous beneficiaries and between local, geographically distinct settlements and broader scale regional communities. Similarly, studies of "social outcomes" may not use "society" as a corresponding category of beneficiary (Urbis 2012) and may identify cobenefits to indigenous communities (e.g., recognition) that directly imply that an effect on a wider population has occurred, without further systematic consideration of those who experience that effect.

Studies incorporating cultural cobenefits (Weir et al. 2011, Pew Charitable Trusts 2015) show a similar orientation. Cultural cobenefits are described as outcomes for indigenous cultures and communities, rather than for nonindigenous cultures and communities. This assumption that culture refers solely to the culture of indigenous people is a common feature in discussions of indigeneity more broadly, but is rarely made explicit (Jackson 2006). Assumptions about culture, combined with the focus on indigenous people and communities as the primary beneficiaries, has constrained consideration of the full array of cultural cobenefits being generated and who is receiving them.

Studies of economic cobenefits tend to contain the most explicit consideration of beneficiaries beyond the local ICNRM context. This is partly through the use of standard economic approaches such as multiplier effects (Allen Consulting Group 2011) or stakeholder identification in social return on investment analyses (Social Ventures Australia 2016). However, it can also arise from political considerations about the intended audience for the work (Pew Charitable Trusts 2015). Even in the economic literature, there are significant variations in the way that recipients are identified, the degree to which cobenefit categories are applied to them, and therefore, the type and extent of cobenefits that may accrue (Greiner and Stanley 2013).

\section{Cobenefit evidence in Australian indigenous cultural and natural resource management}

We next use the preceding identified conceptual insights and clarifications to report on key evidence for ICNRM cobenefits in the Australian literature. The evidence is primarily organized in terms of the cobenefit subcategories identified above, but issues or examples of beneficiary identification are noted where they are analytically important.

\section{Health and well-being cobenefits}

Indigenous health is frequently defined in the literature in terms of the broader concept of well-being (Social Health Reference Group 2004, Prout 2012, Browne-Yung et al. 2013). This reflects the perspectives of indigenous people (Anderson 1996, Greiner et al. 2005, Rigby et al. 2011, Kingsley et al. 2013), as well as longstanding international definitions encompassing mental and physical well-being rather than merely the absence of illness (World Health Organization 1948). Uncritical adoption of terms such as "holism" to characterize indigenous health have been interrogated (Lutschini 2005), but commentators have also noted the "striking similarity" between Western and indigenous understanding of well-being (Kingsley et al. 2009b). 
The connection between indigenous well-being and the perceived health of landscapes and waterways is regularly emphasized (Willis et al. 2004, Johnston et al. 2007, Ganesharajah 2009, Weir 2009, Rigby et al. 2011, Biddle and Swee 2012, Green and Minchin 2012, Kingsley et al. 2013). Residence in smaller communities on traditional lands appears to correlate with mental well-being (Morice 1976) and with specific biomedical health indicators (McDermott et al. 1998, Rowley et al. 2008). However, such evidence requires further interrogation (Kowal 2009, Anderson and Kowal 2012) because it is directly implicated in broader debates about both the value and viability of these smaller communities (Rowley et al. 2006, Hunter 2007, Dockery 2010, Anderson and Kowal 2012) and the implications of changes to the systems of rights that underpin remote residence (Flick and Nelson 1994, Scrimgeour 2007, Watson 2007). A number of studies have highlighted the importance of subsistence foods (Meehan 1982, Altman 1987, Barber 2005, Bliege Bird and Bird 2008, Jackson et al. 2012). However, the potential health benefits of food consumption are more often inferred (Johnston et al. 2007, Prout 2012) than overtly linked or directly demonstrated (O'Dea 1984, O’Dea et al. 1988, Rouja et al. 2003). There are also few available measures and analyses of subsistence food access and food security.

With respect to ICNRM activity and health, the major existing data set derives from a multidisciplinary project, "Healthy Country, Healthy People" (Burgess et al. 2005, 2008, 2009, Johnston et al. 2007, Franklin et al. 2008, Garnett et al. 2009). This project had two key components: quantitative ecological research comparing landscape health under contrasting indigenous and nonindigenous land management regimes, and comparisons of the health and well-being of indigenous participants in land management compared with nonparticipants. The project found ICNRM to be beneficial for clinically measured health indicators and to be associated with lower levels of psychological distress (Burgess et al. 2008, 2009) through associated improvements in diet, physical activity, autonomy, and social and spiritual connection to land (Burgess et al. 2005, 2009). Extrapolations of the work provided preliminary evidence for potential social and emotional well-being benefits (Berry et al. 2010), a basis for calculating health care cost savings (Campbell et al. 2011), and provided further evidence of the value of residence on traditional lands (Johnston et al. 2007).

Subsequent health cobenefit research has focused on policy implications and analysis (Garnett et al. 2009, Campbell et al. 2011) and on review and synthesis (Ganesharajah 2009, Davies et al. 2010, 2011). A systematic review (Davies et al. 2010) of the relationships between health and well-being, ICNRM, and "traditional culture" in the ISI Web of Knowledge database highlighted the importance of the Australian literature in this field: of 17 directly relevant articles, 11 were from Australia. The evidence presented for health and well-being benefits was variously theoretical or review (three articles), biomedical (five), qualitative interview (six), qualitative observation (one), qualitative ethnographic (one), and biochemical (one; Davies et al. 2010). Diverse categories of health indicators were also identified across these studies: general and unspecified (e.g., selfreported well-being), psycho-social (e.g., self-esteem, cultural connection), biomedical (e.g., body mass, diabetes), diet (e.g., diversity, protein intake), and socioeconomic (e.g., income, education; Davies et al 2010). The benefits were variously associated with "caring for country" (Burgess et al. 2009, Kingsley et al. 2009), homeland residence (Morice 1976, O’Dea et al. 1988, McDermott et al. 1998, Rowley et al. 2008), or customary fishing (Rouja et al. 2003). The findings of this review are broadly consistent with the empirical evidence generated from the "Healthy Country, Healthy People" study (Burgess et al. 2009).

Davies et al. (2011) also identify that although significant health improvements are attributed to ICNRM in the literature, they are primarily correlations, with causation inferred rather than demonstrated. However, ICNRM is also understood as "consistent with [indigenous peoples'] own sense of the right and proper way for them to behave towards land, family, and community" (Davies et al. 2011:417), enabling a sense of control and reducing stress (Green and Martin 2016). Physical activity relating to formal and informal ICNRM and to customary education in significant locations has been reported as the most culturally appropriate form of exercise (Thompson et al. 2013). This highlights potentially complex causal relationships between culture, place, physical activity, and health underlying indigenous assertions of the connection between ICNRM and well-being (Greiner et al. 2007, Green and Martin 2016, Robinson et al. 2016). The direct implications of these correlations for health management policies and practices have not been extensively explored, but indigenous well-being indicators that might inform such policy change have been posited, encompassing measures of the ability to access, manage, and control important places, as well as the biophysical condition of those places (Prout 2012).

With respect to beneficiaries, the ICNRM health cobenefit literature focuses entirely on consequences for local indigenous people rather than implications for the wider population. One study calculated the economic implications of ICNRM health outcomes for the national health system (Campbell et al. 2011), but consistent with the conceptual analysis outlined above, other potentially plausible cobenefits to nonindigenous populations have not been considered. Purely based on first principles, such cobenfits could include the direct effects of reduced intercultural trauma and communicable disease rates, the amenity consequences of improved management of natural landscapes, and the well-being cobenefits derived from ICNRM enablement of intercultural learning and social reconciliation processes.

\section{Social cobenefits}

General awareness of the social cobenefits of ICNRM has existed since the early years of the indigenous natural resource management movement (Young et al. 1991, Baker et al. 2001), but it only became the subject of formal analysis more recently (Gilligan 2006). This category is interpreted the most broadly (and arguably inconsistently) within the existing literature, and so a diverse array of cobenefits is reported under the term. Consistent with the subcategory definition (Table 2), the emphasis here is on ICNRM effects on networks, structures, systems, and institutions. We summarized the social cobenefits meeting this definition that are reported in more than one source (Table 3 ). These cobenefits encompass scales ranging from individual families and communities to wider governmental and institutional objectives. Some cobenefits identified by multiple studies as social, for example, "individual and/or community self-worth" (Gilligan 2006, Sithole et al. 2008, Hunt 2010), are more accurately 
Table 3. Social cobenefits recorded in the Australian indigenous cultural and natural resource management literature.

\begin{tabular}{ll}
\hline \hline Social cobenefit & Source \\
\hline Family and community structures and functions & $\begin{array}{l}\text { Gilligan (2006), Greiner et al. (2007), Hunt (2010), Urbis (2012), Green and Martin } \\
(2016), \text { Social Ventures Australia (2016) }\end{array}$ \\
$\begin{array}{l}\text { Social cohesion } \\
\text { Mitigation of substance abuse }\end{array}$ & $\begin{array}{l}\text { Gilligan (2006), Hunt (2010), Urbis (2012), Robinson et al. (2016) } \\
\text { Mitigation of crime and violence levels }\end{array}$ \\
$\begin{array}{ll}\text { Creiner et al. (2007), Sithole et al. (2008), Urbis (2012), Social Ventures Australia (2016) } \\
\text { Gildhood educational attendance and engagement }\end{array}$ & $\begin{array}{l}\text { Gilligan (2006), Hunt (2010), Urbis (2012), Social Ventures Australia (2016), Robinson et } \\
\text { al. (2016) }\end{array}$ \\
Vocational training opportunities & Greiner et al. (2007), Urbis (2012), Robinson et al. (2016) \\
Access to social services & Gilligan (2006), Hunt (2010), Social Ventures Australia (2016) \\
External engagement, networking, and recognition & Sithole et al. (2008), Pew Charitable Trusts (2015), Social Ventures Australia (2016) \\
Targeting and coordination of research & Sithole et al. (2008), Urbis (2012) \\
Delivery of government social objectives & Gilligan (2006), Hunt (2010), Social Ventures Australia (2016)
\end{tabular}

allocated to another subcategory in our definitions (in this case, health and well-being). This is a specific example of the broader issue of the variability with which the social cobenefit category is often defined (or, more accurately, remains undefined).

Three recent and high-profile contributions to the literature further highlight this variability. Urbis (2012) posited an initial contrast between social and economic outcomes and then focused on the former as an all-inclusive category that encompassed cultural, health, well-being and financial outcomes. The latter is presumably distinguished in some way from economic outcomes, perhaps through contrasts in scale with respect to beneficiaries (individual financial vs. wider economic), but the distinction is not made clear. A more recent report from a nongovernment source (Pew Charitable Trusts 2015) had some structural similarities, juxtaposing two major subcategories of benefit (economic and well-being), with the well-being subcategory being further demarcated into "economic and employment," "cultural and social," "health and well-being," and "environment" components. A third recent report (Social Ventures Australia 2016) used an explicit "social return on investment" framework to generate a cost-benefit analysis of social, economic, cultural, and environmental outcomes. In conceptual terms, that study uses social to refer to both the overall suite of cobenefits and a particular subcategory of cobenefit (Social Ventures Australia 2016).

With respect to beneficiaries, we noted above some key examples within social cobenefits reporting: the focus on local indigenous beneficiaries, the use of community to refer to both discrete indigenous settlements and wider regional populations, and that analyses of social cobenefits rarely use society as a corresponding category of beneficiary. Recent studies have provided conceptual frameworks or diagrams that combine subcategories of cobenefits and beneficiaries, either "individuals-families-communities" (Urbis 2012) or "national" and "indigenous community" respectively (Pew Charitable Trusts 2015). Studies that include empirical work with external stakeholders do at times contain better accounts of nonlocal or external benefits and beneficiaries, but the implications of such work can be limited by a number of factors such as an orientation toward local indigenous cobenefits (Greiner et al. 2007, Urbis 2012), the use of standardized conceptual frameworks that are not tailored to indigenous contexts, or a focus on cobenefits that are amenable to numerical valuation (Social Ventures Australia 2016). With respect to subsequent assessment and valuation, Urbis (2012:77-79) contains a useful consideration of potential indicators. These, like empirical observations of cobenefits, can be effectively repositioned, refined, and extended by the adoption of more comprehensive and clearly defined typologies of benefits and beneficiaries.

\section{Cultural cobenefits}

Culture, as both discourse and practice, is a key feature of Australian indigenous contexts. The distinctive characteristics of indigenous cultures are often emphasized by indigenous people themselves and are a significant element in indigenous participation in environmental discourse and policy (Jackson 2006). This emphasis is also reflected in the ICNRM cobenefits literature. However, the profile of cultural cobenefits, i.e., those pertaining to learned behaviors, values, knowledge, etc., that sustain shared identities, also raises questions of scope and demarcation, particularly with respect to social cobenefits. Some analyses have combined the cultural and social into one category (Pew Charitable Trusts 2015). Others have noted the practical difficulty of explicitly separating the two but, nevertheless, employed a working demarcation anyway (Weir et al. 2011). Commonly in the ICNRM literature, the (usually unacknowledged) demarcation problem is resolved by (usually implicitly) resorting to a distinction in beneficiaries, i.e., cultural cobenefits accrue exclusively to indigenous people. This deprioritizes the need for further demarcation of the category, but also constrains overt consideration of the influence of ICNRM on nonindigenous cultural behaviors, values, and ideas. As a result, these influences are either unobserved, unreported, deprioritized, or conceptually misclassified.

The cultural cobenefits that are reported in the literature include enhancements in: indigenous identity, pride, continuity, reinvigoration, and intergenerational respect (Greiner et al. 2007, Johnston et al. 2007, Sithole et al. 2008, Hunt et al. 2009, Griffiths and Kinnane 2010, Urbis 2012, Russell-Smith et al. 2013, Robinson et al. 2016); cultural transmission and intergenerational knowledge transfer (Gilligan 2006, Morrison 2007, Sithole et al. 2008); residence and connections to country (Marika et al. 2012, Pew Charitable Trusts 2015, Green and Martin 2016); and cultural autonomy (Morrison 2007, Yanner 2008). The ongoing cultural consequences of ICNRM are crucial to their success in diverse 
geographic and social contexts within indigenous Australia. Cultural effects on nonindigenous people are far less commonly reported but can include the transformation of previous attitudes and behaviors and the mitigation of racism (Sithole et al. 2008, Hunt et al. 2009, Urbis 2012). Learning and knowledge acquisition by nonindigenous people as part of ICNRM engagement is an important cultural cobenefit, laying foundations for social cobenefits such as reconciliation between indigenous and nonindigenous Australians, and in turn for the realization of wider political cobenefits such as recognition. Greater attention to accurate subcategory definitions and their application and to the full suite of cobenefit beneficiaries is likely to increase substantially the reporting of cultural cobenefits beyond local indigenous communities, with consequently greater awareness of their effect on broader cultural and social systems.

\section{Political cobenefits}

ICNRM organizations striving to meet their objectives and their funder and community responsibilities are enmeshed in ongoing negotiations about the use, management, and governance of natural and cultural resources and about the role of indigenous people in those processes. Overtly constituted indigenous political and representative organizations may occupy formal representative roles, but ICNRM organizations can wield considerable "soft" influence, and there can often be significant overlap in the membership of ICNRM agencies and political or representative organizations. Therefore, successful ICNRM requires a range of skills and generates a range of cobenefits that relate to resource rights, governance, autonomy, selfempowerment, self-determination, and recognition. This point is supported by a range of observations in existing ICNRM cobenefit studies.

In one early formal survey, indigenous organizations noted better land use and economic options, nonindigenous recognition of indigenous roles in land management, and prospects for native title resolution (Gilligan 2006). Later authors have reported improvements in institutional and governance structures (Sithole et al. 2008), and indigenous leaders and ICNRM participants have identified that improved knowledge of country associated with ICNRM activities can enhance customary governance (Marika et al. 2012), political autonomy (Yanner 2008), and associated capacity to engage with the nonindigenous world (Yanner 2008). Urbis (2012:ii) states that the recognitional aspect of public investment in ICNRM is "central to the demonstrated social benefits of the program," indicating a dialectical element in the social and political aspects of ICNRM processes in which the indigenous recognition associated with ICNRM funding is crucial to the cobenefits it generates for indigenous people, but these cobenefits in turn facilitate further recognition.

Despite these observations, only one review in the existing cobenefit literature employs the term political, and does so as part of a hybrid "socio-political" category (Weir et al. 2011). Clearly, empirical findings have not sufficiently informed accurate conceptual categorization. One likely reason for this is the importance of state bureaucratic resourcing of ICNRM programs (and of the cobenefit surveys of those programs). Clearly, identifying such resource channels as sources for building overt political capacity is problematic. However, growing governance needs and obligations in indigenous communities, notably with respect to native title, make the visibility and sustainability of governance outcomes of particular significance. More sophisticated approaches to analyzing ICNRM outcomes will enable this additional return on the investments being made to be identified better and subsequently valued.

\section{Economic cobenefits}

The final cobenefit category more explicitly focuses on questions and methods of valuation. Indigenous economic activities in regional and remote areas incorporate productive activity beyond conventional public-private and market-State definitions (Rea and Messner 2008, Davies et al. 2010), and there are a range of interdependencies between the state, market, and customary components of economic life (Altman 2005, 2012). ICNRM plays an economically significant role in contemporary livelihoods in regional and remote areas because of the resource dependency, unusual demography, and low economic diversification and labor market participation rates in such areas (Carson 2011). Of the communities surveyed by Gilligan (2006), 95\% reported economic benefits from ICNRM.

The most prominent economic cobenefit to individuals is direct employment through the creation or expansion of a labor market (Gilligan 2006, Hunt 2010). Employment rates in ICNRM can significantly outweigh other sectors such as mining (Hunt 2010, Fogarty 2012). ICNRM also provides productivity improvements through appropriate skills and training (Fogarty et al. 2012, Marika and Roeger 2012, Marika et al. 2012) as well as an employment pathway for long-term unemployed people (Hunt 2010). Importantly, any enhanced capacity tends to stay in the immediate locality because very few training participants leave (Sithole et al. 2008). Policy changes rewarding professionalization have reduced the ICNRM employment footprint, particularly for those on subsidized welfare programs (Gorman and Vemuri 2012). However, improvements to direct livelihood options, pathways, and productivity remain key economic cobenefits.

Increased worker capacity enables additional market-based income flows. Examples include cultural tourism and ecotourism (Hunt 2010); art and craft production (Morphy 1998, Koenig et al. 2011); commercial development of native plants, animals, and medicinal knowledge (Gorman et al. 2008, Wilson et al. 2010, Wettenhall 2014); pastoralism and agriculture (Barber 2013); and government contracts for activities such as weed control and biosecurity monitoring (Muller 2008, Hunt 2010). Income from PES is also growing in importance (Luckert et al. 2007, Muller 2008, Altman 2012, Winer et al. 2012, Greiner and Stanley 2013, Hill et al. 2013). PES may include carbon abatement (Heckbert et al. 2012, Dore et al. 2014, Robinson et al. 2016), biodiversity offsets (Russell-Smith et al. 2013), and feral animal control (Zander 2013). The requirements for generating market-based revenues can pose challenges, notably the relationship of environmental outcomes to cultural priorities and social equity issues (Gorman and Vemuri 2012, Urbis 2012, Fache 2014). However, considerable benefits may arise from income diversification and independence from public-sector funding sources (Heckbert et al. 2010, Fitzsimons et al. 2012, Green and Minchin 2012).

ICNRM programs can also generate economic cobenefits through improved infrastructure (Sithole et al. 2008), including fixed infrastructure. However, the high value placed by indigenous 
society on mobility and on accessing traditional lands makes transport infrastructure of considerable significance. Mobility can be crucial in enabling market-based activities but can also be significant for the customary economic component of individual and communal livelihoods (Altman 1987, Asafu-Adjaye 1996, Barber 2005, Fogarty 2005, Gray et al. 2005, Jackson et al. 2012, 2014).

The literature also contains findings of considerable economic benefits accruing to wider systems and institutions. One study identified positive local economic effects, but also found that the true cost to government of ICNRM programs was significantly (up to $23 \%$ ) lower than the budget cost because of reduced welfare costs and increased tax revenue (Allen Consulting Group 2011). The same study calculated economic multiplier effects and found that local dependencies on nonlocal goods also meant that a significant proportion of economic effects accrued centrally rather than locally (Allen Consulting Group 2011). Another study (Campbell et al. 2011) calculated a healthcare system saving across an indigenous community from the primary health and well-being cobenefits associated with ICNRM involvement. From a national accounting perspective, ICNRM agencies that secure offshore funds are effectively generating national exports, and ICNRM agencies that secure and expend funds from federal and state sources generate state- and regional-level economic cobenefits, respectively.

The healthcare study (Campbell et al. 2011) also demonstrates an additional important conceptual and practical consideration that is most evident in the economic cobenefit literature: the secondary effects derived from primary ICNRM cobenefits. The move to generate secondary economic values from primary cobenefits was recently extended in a wider social return on investment study of five ICNRM programs (Social Ventures Australia 2016). Social Ventures Australia (2016) concluded that investment of $\$ 35.2$ million AUD had generated social, economic, cultural, and environmental returns with an adjusted value of $\$ 96.5$ million AUD. In effect, such economic valuations are a subset of the wider logic of considering secondary consequences of primary cobenefits, the potential health and well-being effects of political cobenefits, the social effects of economic co-benefits, and so on.

The recent social return on investment study was based primarily on an externally generated social return on investment framework rather than an extensive engagement with the existing Australian ICNRM cobenefit literature. The framework has one strength in explicitly directing attention toward external stakeholders (beneficiaries). The total stakeholder list included land councils, local service providers, private landowners, local businesses, and Indigenous Protected Area management, but the emphasis in the study was on a subset of stakeholders for which any derived benefits were amenable to economic valuations. The stakeholders included rangers, community members (including indigenous traditional owners), indigenous corporation partners, nongovernmental organizations, research partners, and local, state, and national governments. The total combined list of stakeholders is relatively extensive, but the subcategories of cobenefit were not consistently applied across all beneficiaries. For example, cultural outcomes were only identified for ICNRM employees and community members, rather than for nongovernmental organizations, government stakeholders, and research partners (where a robust economic proxy such as the cost of a cultural awareness course easily could have been generated). Health and well-being outcomes were not considered beyond ICNRM employees. As a result, this recent contribution to the literature reflects some key trends across the literature as a whole: the increasing pressure for numerical valuation; a lack of overt attention to political cobenefits; improved, but still incomplete, focus on beneficiaries; and the failure to apply cobenefit categories systematically to all beneficiaries, leading to the omission of cobenefits amenable to both identification and subsequent valuation.

\section{DISCUSSION}

\section{Australian indigenous cultural and natural resource management} cobenefit and beneficiary conceptualization

The existing empirical and review literature on Australian ICNRM shows that such programs can generate a diverse range of significant cobenefits: health and well-being, social, cultural, political, and economic. These findings are crucial for demonstrating the ongoing significance of an initiative that is the most striking development in formal Australian land and natural resource management in the past few decades. However, significant inconsistencies and elisions exist that have hampered the identification and analysis of the full suite of potential cobenefits, including deficiencies in social theoretical framing, cobenefit category identification, formal category definition and demarcation, methods that enable empirical findings to inform cobenefit categories iteratively, and systematic attention to cobenefit recipients.

In addition to limiting effective cobenefit identification, these constraints also inhibit the degree to which studies can be evaluated and compared. Our review highlighted that it is not always evident from a given empirical study whether a cobenefit is not present, present but not recorded as data, or recorded but not prioritized in reporting. This is particularly true of certain cobenefit categories (e.g., political benefits) and those accruing to particular beneficiaries (e.g., nonindigenous people). These limitations partly arise because of an understandable focus on immediate outcomes for program participants, in this case, a socially and economically marginalized subgroup of the Australian population. However, they also arise as a consequence of sectoral funding sources (particularly government) and of wider aspects of Australian society such as the emphasis on indigenous culture as a point of distinction and heritage value. Effects can be misrecognized, deprioritized, underspecified, or elided.

\section{Cobenefit assessment, measurement, and evaluation}

Establishing an appropriate conceptual framework for cobenefit identification and categorization provides crucial foundations for effective assessment and measurement. These steps in turn are required to certify projects and products and to secure investment. Sustainability outcomes are currently undervalued in many propoor conservation programs (Olsen 2007, Sutter and Parreño 2007) and in many assessments of climate change impacts (Watts et al. 2015). Taking carbon mitigation schemes as an example, recent studies have identified cobenefit implications for local forest governance (Phelps et al. 2010), synergies and trade-offs between carbon storage and livelihoods (Chhatre and Agrawal 2009), questions of safeguards and cobenefits (Chhatre et al. 2012, 
McDermott et al. 2012, Visseren-Hamakers et al. 2012, Mayrhofer and Gupta 2016), and issues of measurement, information flow (Korhonen-Kurki et al. 2013), and standardization (Olsen 2007).

As fair trade regimes have demonstrated (Duchelle et al. 2014), evidence of the wider socioeconomic benefits of commodity production often takes the form of qualitative local accounts, e.g., self-reported or declared by an indigenous producer, which add market value to those commodities through the depiction of idealized social relations of production (Bumpus 2011, Goodman and Boyd 2011). Clearly, such narratives do not constitute rigorous empirical testing. However, as the Australian examples demonstrate, developments in conservation financing increasingly require clearly defined, verifiable, easily recognized units of value to be traded under contract. Internationally accredited and recognized benchmarking and monitoring programs are considered essential for this process (Fitzsimons et al. 2012). Some successes have been reported (Aunun et al. 2004), assessment methodologies proposed (Sutter 2003), and standards for verification and certification developed. However, such standards remain works in progress (Sutter 2003, Bumpus and Cole 2010).

Proposals for cobenefit indicators in Australian ICNRM (Urbis 2012) remain constrained by the limitations in the frameworks from which they were put forward. Standards and measures of the benefits of natural resource management need to be context specific, collaborative, and relevant to policy making and public action (Hibbard and Lurie 2012). This has resulted in some work on ICNRM that incorporates participatory evaluation and is locally meaningful and transparent (Sithole et al. 2008, Izurieta et al. 2011, Prout 2012, Stacey et al. 2013). However, standardized characterizations of the multiple benefits arising from ICNRM remain underdeveloped, and the metrics and frameworks for integrating values and benefits are not well developed.

There are particular challenges associated with bringing local cultures and knowledge practices within the view of globalized environmental management discourses (Strang 2008, Barbour and Schlesinger 2012, Holmes and Cavanagh 2016). An exhaustive approach to cobenefit identification and assessment would generate a substantial reporting burden. This would be a highly unfavorable outcome in most circumstances, let alone ICNRM contexts characterized by shortages of human skill and financial capital. In Australia, placing greater attention on generating evidence for cobenefits can be depicted as both a form of local bureaucratic capture of the research and monitoring agenda but also as a key pathway to demonstrating the wider significance of ICNRM for a fourth world minority living in a settler colonial nation state. It is both a form of neoliberal intrusion and of potential recognition for indigenous values and ways of life (Altman and Kerins 2012, Jackson et al. 2017).

\section{Implications and pathways for further research}

Economic activity and outcomes are usually central to situations where local communities are experiencing severe poverty that can influence environmental degradation. Welfare state protection can also reduce the effects of low economic activity in a given area. Perhaps partly as a result, relatively few contemporary international studies take the additional positivist step evident in the Australian literature of emphasizing the understanding and assessment of the wider social, cultural, political, and health consequences alongside the economic ones. Policy influence can be a challenging process in which evidence is only one of a range of conditions required (Baum et al. 2013). However, neoliberal and bureaucratic accounting pressures continue to grow, and research agendas will be obliged to respond accordingly (Holmes and Cavanagh 2016). At present, political, economic, and cultural dimensions of propoor sustainable development programs have generally been considered in terms of critique, i.e., revenue distribution, power relations, commodity fetishism, certification as semiotic act, and issues of material practice (Goodman 2004, Corbera et al. 2007, Goodman and Boyd 2011, Marston 2013), rather than in terms of the detailed cobenefit assessment considered here.

Advancement in such assessments will need to incorporate further engagement in diverse field environments and with the continually emerging international literature on cobenefits. Advancement will also be assisted by deeper engagement with more general literature on the individual, community, and national benefits of environmental amenity and action (Sommer et al. 1994, Heliker et al. 2001, Westphal 2003, Peacock et al. 2007, Maller et al. 2009, McClenachan et al. 2015). This literature can be conceptually and empirically constrained, operating under simplistic and reified versions of nature that elide the socio-political creation of natural places (West et al. 2006, Stevens 2014) as well as the coproduction of ecosystem services (Jackson and Palmer 2015). However, such limitations can be counterbalanced by literature that documents ways of valuing the socio-cultural relations between people and nature, which, in the case of literature on fourth world peoples, has variously demonstrated connections between human wellbeing and environmental condition (Willox et al. 2012), access to environmental resources (Richmond et al. 2005), cultural landscapes and places (Wilson 2003), and physical and cultural activity in such places (Wilson and Rosenberg 2002, Schwab 2006, Janelle et al. 2009, Lowan 2009, Jackson et al. 2014).

The trends previously outlined in the Australian context, i.e., increasing interest in multiple outcomes amongst funders, a degree of ignorance or ambivalence about nonenvironmental outcomes from the general public, an absence of systematic national ICNRM survey data, and the ambiguities of statesponsored ICNRM participation, all justify greater understanding of the full effects of ICNRM programs. Based on our analysis, alongside the continued investigation of relevant indicators and metrics and the further investigation of the international literature, additional research is required that demonstrates cobenefit causality rather than correlation, investigates the effects of PES frameworks on cobenefits, and provides more sophisticated accounts of the social, cultural, and political effects of ICNRM on wider nonindigenous society. In contexts in which the political is deidentified and where culture matters greatly but is implicitly assumed not to be evenly distributed, such accounts are locally critical as well as internationally instructive.

\section{CONCLUSION}

Growing public and private investment in Australian ICNRM and associated nascent research interest in the cobenefits arising from this investment are key features of contemporary Australian environmental governance. These have implications well beyond the Australian context, particularly as critical readings of the Australian literature point to a number of basic but important refinements in how to define, categorize, identify, and assign 
recipients systematically to cobenefits that are not, in the first instance, material or economic. Undertaking such clarifications to these first-order noneconomic and nonenvironmental benefits can in turn enable better and more comprehensive second-order economic valuations. Assessments that are not grounded in comprehensive cobenefit and beneficiary frameworks will miss cobenefits that are potentially valuable, in both senses of the term. In turn, valuations based on inadequately defined and demarcated frameworks risk producing overlapping or duplicated estimates. Both of these consequences put researchers (and funding agencies) at risk of misunderstanding the motivations and objectives of ICNRM participants. Such transparent and defensible documentation of the wider positive consequences of environmental action can enable premium project and product prices and in turn increase the share of such projects in global markets. Equally importantly, appropriately conceptualized identification and valuation frameworks can enable local communities to communicate more effectively the true value of such programs to external investors. Local narratives that emphasize environmental holism and the interconnectedness of people, culture, country, and ancestry should be one part of such communication. A clearly defined, consistent, and repeatable cobenefit typology that neither omits nor duplicates beneficial effects and that systematically identifies beneficiaries needs to be another part of the communication.

\section{Responses to this article can be read online at:} http://www.ecologyandsociety.org/issues/responses. $\mathrm{php} / 9114$

\section{Acknowledgments:}

This project was supported by the National Environmental Research Program of the Australian government, by Land and Water of CSIRO, and by Griffith University. S. Jackson was additionally supported by the Australian Research Council's Future Fellowships Program funding scheme (project number FT130101145). We thank the anonymous reviewers of the draft manuscript. All remaining errors are the responsibility of the authors.

\section{LITERATURE CITED}

Adams, W. M., and J. Hutton. 2007. People, parks and poverty: political ecology and biodiversity conservation. Conservation and Society 5(2):147-183. [online] URL: http://www.conservationandsociety. org/text.asp?2007/5/2/147/49228

Adams, W. M., and M. Mulligan, editors. 2003. Decolonizing nature: strategies for conservation in a post-colonial era. Earthscan, London, UK.

Agrawal, A. 2005. Environmentality: community, intimate government, and the making of environmental subjects in Kumaon, India. Current Anthropology 46(2):161-191. http://dx. doi.org/10.1086/427122

Allen Consulting Group. 2011. Assessment of the economic and employment outcomes of the Working on Country program. Report to the Department of Sustainability, Environment, Water, Population and Communities. Allen Consulting Group,
Canberra, Australia. [online] URL: https://www.environment. gov.au/indigenous/workingoncountry/publications/pubs/woc-economics. pdf

Altman, J. C. 1987. Hunter-gatherers today: an Aboriginal economy in north Australia. Australian Institute of Aboriginal Studies, Canberra, Australia.

Altman, J. 2005. Development options on Aboriginal land: sustainable Indigenous hybrid economies in the twenty-first century. Pages 34-48 in L. Taylor, G. K. Ward, G. Henderson, R. Davis, and L. A. Wallis, editors. The power of knowledge: the resonance of tradition. Aboriginal Studies Press, Canberra, Australia.

Altman, J. 2012. Indigenous futures on country. Pages 213-231 in J. Altman and S. Kerins, editors. People on country: vital landscapes, indigenous futures. Federation Press, Sydney, Australia.

Altman, J., and S. Jackson. 2014. Indigenous land and sea management: recognition, redistribution, representation. Pages 27-48 in D. Lindenmayer, S. Dovers, and S. Morton, editors. Ten commitments revisited: securing Australia's future environment. CSIRO Publishing, Melbourne, Australia.

Altman, J., and S. Kerins, editors. 2012. People on country: vital landscapes, indigenous futures. Federation Press, Sydney, Australia.

Anderson, H., and E. Kowal. 2012. Culture, history, and health in an Australian Aboriginal community: the case of utopia. Medical Anthropology 31(5):438-457. http://dx.doi. org/10.1080/01459740.2011.636411

Anderson, I. 1996. Aboriginal well-being. Pages 57-71 in C. Grbich, editor. Health in Australia: sociological concepts and issues. Pearson/Longman, Sydney, Australia.

Asafu-Adjaye, J. 1996. Traditional production activities and resource sustainability: the case of indigenous societies in Cape York Peninsula, Australia. International Journal of Social Economics 23(4/5/6):125-135. http://dx.doi.org/10.1108/0306829$\underline{9610121750}$

Aunun, K., J. Fang, H. Vennemo, K. Oye, and H. M. Seip. 2004. Co-benefits of climate policy-lessons learned from a study in Shanxi, China. Energy Policy 32(4):567-581. http://dx.doi. org/10.1016/s0301-4215(03)00156-3

Baker, R., J. Davies, and E. Young, editors. 2001. Working on country: contemporary indigenous management of Australia's lands and coastal regions. Oxford University Press, Melbourne, Australia.

Barber, M. 2005. Where the clouds stand: Australian Aboriginal attachments to water, place, and the marine environment in Northeast Arnhem land. Dissertation. Australian National University, Canberra, Australia.

Barber, M. 2013. Indigenous water values, rights and interests in the Flinders and Gilbert catchments. A technical report to the Australian Government from the CSIRO Flinders and Gilbert Agricultural Resource Assessment, part of the North Queensland Irrigated Agriculture Strategy. CSIRO Water for a Healthy Country and Sustainable Agriculture flagships. CSIRO, Canberra, Australia. https://doi.org/10.4225/08/584d965bc52b9 
Barber, M. 2015a. Beyond the local: assessing the external social outcomes of Indigenous environmental management. Key concepts and a case study of the Kowanyama Aboriginal Land and Natural Resource Management Office. CSIRO, Brisbane, Australia.

Barber, M. 2015b. Rangers in place: the wider indigenous community benefits of Yirralka Rangers in Blue Mud Bay, northeast Arnhem Land. CSIRO, Brisbane, Australia.

Barbour, W., and C. Schlesinger. 2012. Who's the boss? Postcolonialism, ecological research and conservation management on Australian Indigenous lands. Ecological Management and Restoration 13(1):36-41. http://dx.doi.org/10.1111/j.1442-8903.2011.00632. $\underline{\mathrm{x}}$

Baum, F. E., P. Laris, M. Fisher, L. Newman, and C. MacDougall. 2013. "Never mind the logic, give me the numbers": Former Australian health ministers' perspectives on the social determinants of health. Social Science and Medicine 87:138-146. http://dx.doi.org/10.1016/j.socscimed.2013.03.033

Bauman, T., C. Haynes, and G. Lauder. 2013. Pathways to the comanagement of protected areas and native title in Australia. Australian Institute of Aboriginal and Torres Strait Islander Studies, Canberra, Australia. [online] URL: http://aiatsis.gov.au/ publications/products/pathways-co-management-protected-areasand-native-title-australia

Berry, H. L., J. R. A. Butler, C. P. Burgess, U. G. King, K. Tsey, Y. L. Cadet-James, C. W. Rigby, and B. Raphael. 2010. Mind, body, spirit: co-benefits for mental health from climate change adaptation and caring for country in remote Aboriginal Australian communities. New South Wales Public Health Bulletin 21(6):139-145. http://dx.doi.org/10.1071/NB10030

Biddle, N., and H. Swee. 2012. The relationship between wellbeing and Indigenous land, language and culture in Australia. Australian Geographer 43(3):215-232. http://dx.doi. org/10.1080/00049182.2012.706201

Bliege Bird, R., and D. W. Bird. 2008. Why women hunt: risk and contemporary foraging in a Western Desert Aboriginal community. Current Anthropology 49(4):655-693.

Borrini-Feyerabend, G., A. Kothari, and G. Oviedo. 2004. Indigenous and local communities and protected areas: towards equity and enhanced conservation. Best Practice Protected Area Guidelines Series 11. IUCN, Gland, Switzerland. [online] URL: https://portals.iucn.org/library/sites/library/files/documents/PAG-011. pdf

Bradley, J. 2010. Singing saltwater country: journey to the songlines of Carpentaria. Allen and Unwin, Melbourne, Australia.

Browne-Yung, K., A. Ziersch, F. Baum, and G. Gallaher. 2013. Aboriginal Australians' experience of social capital and its relevance to health and wellbeing in urban settings. Social Science and Medicine 97:20-28. http://dx.doi.org/10.1016/j.socscimed.2013.08.002

Bumpus, A. 2011. Realising local development in the carbon commodity chain: political economy, value and connecting carbon commodities at multiple scales. Occasional Paper 3. United Nations Research Institute for Social Development, Geneva, Switzerland. [online] URL: http://www.fes-globalization.org/ geneva/documents/3\%20Bumpus $\% 20$ Occasional $\% 20$ Paper.pdf
Bumpus, A. G., and J. C. Cole. 2010. How can the current CDM deliver sustainable development? Wiley Interdisciplinary Reviews: Climate Change 1(4):541-547. http://dx.doi.org/10.1002/wcc.57

Burgess, C. P., H. L. Berry, W. Gunthorpe, and R. S. Bailie. 2008. Development and preliminary validation of the 'Caring for Country' questionnaire: measurement of an Indigenous Australian health determinant. International Journal for Equity in Health 7:26. http://dx.doi.org/10.1186/1475-9276-7-26

Burgess, C. P., F. H. Johnston, H. L. Berry, J. McDonnell, D. Yibarbuk, C. Gunabarra, A. Mileran, and R. S. Bailie. 2009. Healthy country, healthy people: the relationship between Indigenous health status and "caring for country". Medical Journal of Australia 190(10):567-572. [online] URL: https://www. mja.com.au/system/files/issues/190 10 180509/bur11368 fm.pdf

Burgess, C. P., F. H. Johnston, D. M. J. S. Bowman, and P. J. Whitehead. 2005. Healthy country: healthy people? Exploring the health benefits of Indigenous natural resource management. Australian and New Zealand Journal of Public Health 29 (2):117-122. http://dx.doi.org/10.1111/j.1467-842X.2005.tb00060. $\underline{\mathrm{x}}$

Campbell, D., C. P. Burgess, S. T. Garnett, and J. Wakerman. 2011. Potential primary health care savings for chronic disease care associated with Australian Aboriginal involvement in land management. Health Policy 99(1):83-89. http://dx.doi.org/10.1016/ j.healthpol.2010.07.009

Campbell, D., J. Davies, and J. Wakerman. 2007. Realising economies in the joint supply of health and environmental services in Aboriginal central Australia. Desert Knowledge CRC Working Paper 11. Desert Knowledge CRC, Alice Springs, Australia. [online] URL: https://www.crh.org.au/administrator/components/ com jresearch/files/publications/realising-economies-in-the-jointsupply-of-health-and-environmental-services-in-aboriginal-centralaustralia-campbell-d-davies-j-wakerman-j.pdf

Campbell, D., J. Davies, and J. Wakerman. 2008. Facilitating complentary inputs and scoping economies in the joint supply of health and environmental services in Aboriginal central Australia. Rural and Remote Health 8(4):1010. [online] URL: http://www. rrh.org.au/articles/subviewnew.asp?ArticleID=1010

Carson, D. 2011. Political economy, demography and development in Australia's Northern Territory. Canadian Geographer 55(2):226-242. http://dx.doi.org/10.1111/

j.1541-0064.2010.00321.X

Chhatre, A., and A. Agrawal. 2009. Trade-offs and synergies between carbon storage and livelihood benefits from forest commons. Proceedings of the National Academy of Sciences 106 (42):17667-17670. http://dx.doi.org/10.1073/pnas.0905308106

Chhatre, A., S. Lakhanpal, A. M. Larson, F. Nelson, H. Ojha, and J. Rao. 2012. Social safeguards and co-benefits in REDD+: a review of the adjacent possible. Current Opinion in Environmental Sustainability 4(6):654-660. http://dx.doi.org/10.1016/ j.cosust.2012.08.006

Corbera, E., K. Brown, and W. N. Adger. 2007. The equity and legitimacy of markets for ecosystem services. Development and Change 38(4):587-613. http://dx.doi.org/10.1111/j.1467-7660.2007.00425. 
Davies, J., D. Campbell, M. Campbell, J. Douglas, H. Hueneke, M. LaFlamme, D. Pearson, K. Preuss, J. Walker, and F. Walsh. 2010. Livelihoods inland: promoting health and wellbeing outcomes from desert Aboriginal land management. Desert Knowledge CRC Report 78. Desert Knowledge CRC, Alice Springs, Australia. [online] URL: http://www.desertknowledgecrc.com.au/resource/ dkcrc-report-78-livelihoods-in-land health-and-wellbeing-fromdesert-alm.pdf

Davies, J., D. Campbell, M. Campbell, J. Douglas, H. Hueneke, M. LaFlamme, D. Pearson, K. Preuss, J. Walker, and F. Walsh. 2011. Attention to four key principles can promote health outcomes from desert Aboriginal land management. Rangeland Journal 33(4):417-431. http://dx.doi.org/10.1071/RJ11031

Davies, J., R. Hill, F. J. Walsh, M. Sandford, D. Smyth, and M. C. Holmes. 2013. Innovation in management plans for community conserved areas: experiences from Australian indigenous protected areas. Ecology and Society 18(2):14. http://dx.doi. org/10.5751/es-05404-180214

Dockery, A. M. 2010. Culture and wellbeing: the case of indigenous Australians. Social Indicators Research 99(2):315-332. http://dx.doi.org/10.1007/s11205-010-9582-y

Dore, J., C. Michael, J. Russell-Smith, M. Tehan, and L. Caripis. 2014. Carbon projects and Indigenous land in northern Australia. Rangeland Journal 36(4):389-402. http://dx.doi.org/10.1071/ $\underline{\mathrm{RJ} 13128}$

Duchelle, A. E., K. A. Kainer, and L. H. O. Wadt. 2014. Is certification associated with better forest management and socioeconomic benefits? A comparative analysis of three certification schemes applied to Brazil nuts in western Amazonia. Society and Natural Resources 27(2):121-139. http://dx.doi. org/10.1080/08941920.2013.840022

Fache, E. 2014. Caring for country, a form of bureaucratic participation. Conservation, development, and neoliberalism in Indigenous Australia. Anthropological Forum 24(3):267-286. http://dx.doi.org/10.1080/00664677.2014.939576

Fitzsimons, J., J. Russell-Smith, G. James, T. Vigilante, G. LipsettMoore, J. Morrison, and M. Looker. 2012. Insights into the biodiversity and social benchmarking components of the northern Australian fire management and carbon abatement programmes. Ecological Management and Restoration 13 (1):51-57. http://dx.doi.org/10.1111/j.1442-8903.2011.00624.x

Flick, B., and B. Nelson. 1994. Land and indigenous health. Pages 1-7 in Land, rights, laws: issues of native title. Volume 1, issue 3. Australian Institute of Aboriginal and Torres Strait Islander Studies, Canberra, Australia.

Fogarty, W. 2005. 'You got any truck?': Vehicles and decentralised mobile service-provision in remote Indigenous Australia. Working Paper 30. Centre for Aboriginal Economic Policy Research, Canberra, Australia. [online] URL: http://caepr.anu.edu.au/sites/ default/files/Publications/WP/CAEPRWP30.pdf

Fogarty, W. 2012. Country as classroom. Pages 82-93 in J. Altman and S. Kerins, editors. People on country: vital landscapes, indigenous futures. Federation Press, Sydney, Australia.
Fogarty, W., V. Rostron, W. Campion, and I. Namarnyilk. 2012. Countrymen standing together. Pages 162-173 in J. Altman and S. Kerins, editors. People on country: vital landscapes, indigenous futures. Federation Press, Sydney, Australia.

Franklin, D. C., A. M. Petty, G. J. Williamson, B. W. Brook, and D. M. J. S. Bowman. 2008. Monitoring contrasting land management in the savanna landscapes of northern Australia. Environmental Management 41(4):501-515. http://dx.doi.org/10.1007/ s00267-007-9006-1

Gammage, B. 2011. The biggest estate on Earth: how Aborigines made Australia. Allen and Unwin, Sydney, Australia.

Ganesharajah, C. 2009. Indigenous health and wellbeing: the importance of country. Australian Institute of Aboriginal an Torres Strait Islander Studies, Canberra, Australia. [online] URL: http://aiatsis.gov.au/sites/default/files/products/report research outputs/ ganesharajah-2009-indigenous-health-wellbeing-importance-country. pdf

Garnett, S. T., B. Sithole, P. J. Whitehead, C. P. Burgess, F. H. Johnston, and T. Lea. 2009. Healthy country, healthy people: policy implications of links between Indigenous human health and environmental condition in tropical Australia. Australian Journal of Public Administration 68(1):53-66. http://dx.doi. org/10.1111/j.1467-8500.2008.00609.x

Gilligan, B. 2006. The Indigenous Protected Areas program - 2006 evaluation. Department of the Environment and Heritage, Canberra, Australia. [online] URL: https://www.environment. gov.au/indigenous/publications/ipa-evaluation.html

Goodman, M. K. 2004. Reading fair trade: political ecological imaginary and the moral economy of fair trade foods. Political Geography 23(7):891-915. http://dx.doi.org/10.1016/j.polgeo.2004.05.013

Goodman, M. K., and E. Boyd. 2011. A social life for carbon? Commodification, markets and care. Geographical Journal 177 (2):102-109. http://dx.doi.org/10.1111/j.1475-4959.2011.00401.x

Gorman, J., and S. Vemuri. 2012. Social implications of bridging the gap through 'caring for country' in remote Indigenous communities of the Northern Territory, Australia. Rangeland Journal 34(1):63-73. http://dx.doi.org/10.1071/RJ11037

Gorman, J. T., P. J. Whitehead, A. D. Griffiths, and L. Petheram. 2008. Production from marginal lands: indigenous commercial use of wild animals in northern Australia. International Journal of Sustainable Development and World Ecology 15(3):240-250. http://dx.doi.org/10.3843/susdev.15.3:7

Gray, M., J. Altman, and N. Halasz. 2005. The economic value of wild resources to the Indigenous community of the Wallis Lake catchment. Discussion Paper 272. Centre for Aboriginal Economic Policy Research, Australian National University, Canberra, Australia. [online] URL: http://caepr.anu.edu.au/sites/ default/files/Publications/DP/2005 DP272.pdf

Green, D., and D. Martin. 2016. Maintaining the healthy countryhealthy people nexus through sociocultural and environmental transformations: challenges for the Wik Aboriginal people of Aurukun, Australia. Australian Geographer. http://dx.doi. org/10.1080/00049182.2016.1220898 
Green, D., and L. Minchin. 2012. The co-benefits of carbon management on country. Nature Climate Change 2:641-643. http://dx.doi.org/10.1038/nclimate1643

Greiner, R., S. Larson, A. Herr, and V. Bligh. 2005. Wellbeing of Nywaigi traditional owners: the contribution of country to wellbeing and the role of natural resource management. CSIRO Sustainable Ecosystems, Townsville, Australia. [online] URL: http://www.cse. csiro.au/publications/2005/nywaigiwellbeing.pdf

Greiner, R., L. Patterson, V. Bligh, and S. Milligan. 2007. Wellbeing of traditional owners: contributions by Girringun Aboriginal Corporation. River Consulting, Townsville, Australia.

Greiner, R., and O. Stanley. 2013. More than money for conservation: exploring social co-benefits from PES schemes. Land Use Policy 31:4-10. http://dx.doi.org/10.1016/j. landusepol.2011.11.012

Griffiths, A., and S. Kinnane. 2010. Kimberley Aboriginal Caring for Country plan. Kimberley Language Resource Centre, Broome, Australia.

Heckbert, S., J. Russell-Smith, and J. Davies. 2010. Northern savanna fire abatement and greenhouse gas offsets on indigenous lands. Chapter 25, pages 1-15 in P. Stone, editor. Northern Australia land and water science review 2009. CSIRO Publishing, Canberra, Australia. [online] URL: http://www.northernaustralia. gov.au/sites/prod.office-northern-australia.gov.au/files/ files/337388 NLAW Review 2009.pdf

Heckbert, S., J. Russell-Smith, A. Reeson, J. Davies, G. James, and C. Meyer. 2012. Spatially explicit benefit-cost analysis of fire management for greenhouse gas abatement. Austral Ecology 37 (6):724-732. http://dx.doi.org/10.1111/j.1442-9993.2012.02408.x

Heliker, D., A. Chadwick, and T. O'Connell. 2001. The meaning of gardening and the effects on perceived well being of a gardening project on diverse populations of elders. Activities, Adaptation and Aging 24(3):35-56. http://dx.doi.org/10.1300/J016v24n03 03

Hibbard, M., and S. Lurie. 2012. Creating socio-economic measures for community-based natural resource management: a case from watershed stewardship organisations. Journal of Environmental Planning and Management 55(4):525-544. http:// dx.doi.org/10.1080/09640568.2011.614093

Hill, R., P. L. Pert, J. Davies, C. J. Robinson, F. Walsh, and F. Falco-Mammone. 2013. Indigenous landmanagement in Australia: extent, scope, diversity, barriers and success factors. CSIRO Ecosystem Sciences, Cairns, Australia. [online] URL: http://www. agriculture.gov.au/SiteCollectionDocuments/natural-resources/landcare/ submissions/ilm-report.pdf

Holmes, G., and C. J. Cavanagh. 2016. A review of the social impacts of neoliberal conservation: formations, inequalities, contestations. Geoforum 75:199-209. http://dx.doi.org/10.1016/j. geoforum.2016.07.014

Hunt, J. 2010. Looking after country in New South Wales: two case studies of socioeconomic benefits for Aboriginal people. CAEPR Working Paper 75/2010. Centre for Aboriginal Economic Policy Research, Australian National University, Canberra, Australia. [online] URL: http://caepr.anu.edu.au/sites/default/files/Publications/ WP/WP75.pdf
Hunt, J., J. Altman, and K. May. 2009. Social benefits of Aboriginal engagement in Natural Resource Management. CAEPR Working Paper 60/2009. Centre for Aboriginal Economic Policy Research, Australian National University, Canberra, Australia. [online] URL: http://caepr.anu.edu.au/sites/ default/files/Publications/WP/CAEPRWP60.pdf

Hunter, E. 2007. Disadvantage and discontent: a review of issues relevant to the mental health of rural and remote indigenous Australians. Australian Journal of Rural Health 15(2):88-93. http://dx.doi.org/10.1111/j.1440-1584.2007.00869.x

Izurieta, A., B. Sithole, N. Stacey, H. Hunter-Xenie, B. Campbell, P. Donohoe, J. Brown, and L. Wilson. 2011. Developing indicators for monitoring and evaluating joint management effectiveness in protected areas in the Northern Territory, Australia. Ecology and Society 16(3):9. http://dx.doi.org/10.5751/es-04274-160309

Jackson, S. 2006. Compartmentalising culture: the articulation and consideration of Indigenous values in water resource management. Australian Geographer 37(1):19-31. http://dx.doi. org/10.1080/00049180500511947

Jackson, E. T. 2013. Evaluating social impact bonds: questions, challenges, innovations, and possibilities in measuring outcomes in impact investing. Community Development 44(5):608-616. http://dx.doi.org/10.1080/15575330.2013.854258

Jackson, S., M. Finn, and P. Featherston. 2012. Aquatic resource use by indigenous Australians in two tropical river catchments: the Fitzroy River and Daly River. Human Ecology 40(6):893-908. http://dx.doi.org/10.1007/s10745-012-9518-Z

Jackson, S., M. Finn, and K. Scheepers. 2014. The use of replacement cost method to assess and manage the impacts of water resource development on Australian indigenous customary economies. Journal of Environmental Management 135:100-109. http://dx.doi.org/10.1016/j.jenvman.2014.01.018

Jackson, S., and L. R. Palmer. 2015. Reconceptualizing ecosystem services: possibilities for cultivating and valuing the ethics and practices of care. Progress in Human Geography 39(2):122-145. http://dx.doi.org/10.1177/0309132514540016

Jackson, S., L. Palmer, F. McDonald, and A. Bumpus. 2017. Cultures of carbon and the logic of care: the possibilities for carbon enrichment and its cultural signature. Annals of the American Association of Geographers. http://dx.doi. org/10.1080/24694452.2016.1270187

Janelle, A., A. Laliberté, and U. Ottawa. 2009. Promoting traditions: an evaluation of a wilderness activity among First Nations of Canada. Australasian Psychiatry 17(S1):S108-S111. http://dx.doi.org/10.1080/10398560902948605

Johnston, F. H., S. P. Jacups, A. J. Vickery, and D. M. J. S. Bowman. 2007. Ecohealth and Aboriginal testimony of the nexus between human health and place. EcoHealth 4(4):489-499. http://dx.doi. org/10.1007/s10393-007-0142-0

Kerins, S. 2013. Social enterprise as a model for developing Aboriginal lands. CAEPR Topical Issue 4/2013. Centre for Aboriginal Economic Policy Research, Australian National University, Canberra, Australia. [online] URL: http://caepr.anu. edu.au/sites/default/files/Publications/topical/TI2013 05 Kerin$\underline{\text { s social enterprise.pdf }}$ 
Kingsley, J., D. Aldous, M. Townsend, R. Phillips, and C. Henderson-Wilson. 2009a. Investigating health, economic and socio-political factors that need consideration when establishing Victorian Aboriginal land management projects. Australasian Journal of Environmental Management 16(2):113-123. http://dx. doi.org/10.1080/14486563.2009.9725225

Kingsley, J., M. Townsend, C. Henderson-Wilson, and B. Bolam. 2013. Developing an exploratory framework linking Australian Aboriginal peoples' connection to country and concepts of wellbeing. International Journal of Environmental Research and Public Health 10(2):678-698. http://dx.doi.org/10.3390/ijerph10020678

Kingsley, J., M. Townsend, R. Phillips, and D. Aldous. 2009b. "If the land is healthy ... it makes the people healthy": The relationship between caring for country and health for the Yorta Yorta Nation, Boonwurrung and Bangerang Tribes. Health and Place 15(1):291-299. http://dx.doi.org/10.1016/j.healthplace.2008.05.009

Koenig, J., J. Altman, and A. D. Griffiths. 2011. Indigenous livelihoods and art income: participation, production and returns from woodcarvings in Arnhem Land, north Australia. Australian Geographer 42(4):351-369. http://dx.doi.org/10.1080/00049182.$\underline{2011.619952}$

Kollmuss, A., H. Zink, and C. Polycarp. 2008. Making sense of the voluntary carbon market: a comparison of carbon offset standards. WWF, Berlin, Germany. [online] URL: http://www. globalcarbonproject.org/global/pdf/WWF 2008 A\%20comparison $\%$ 20of $\% 20 \mathrm{C} \% 20$ offset $\% 20$ Standards.pdf

Korhonen-Kurki, K., M. Brockhaus, A. E. Duchelle, S. Atmadja, P. Thu Thuy, and L. Schofield. 2013. Multiple levels and multiple challenges for measurement, reporting and verification of REDD+. International Journal of the Commons 7(2):344-366. http://dx.doi.org/10.18352/ijc.372

Kowal, E. E. 2009. Patterns of mortality in Indigenous adults in the Northern Territory, 1998-2003. Medical Journal of Australia 191(10):581-582. [online] URL: https://www.mja.com.au/system/ files/issues/191_10_161109/letters_161109_fm-8.pdf

Lowan, G. 2009. Exploring place from an Aboriginal perspective: considerations for outdoor and environmental education. Canadian Journal of Environmental Education 14:42-58. [online] URL: https://cjee.lakeheadu.ca/article/view/885/618

Luckert, M. K., B. M. Campbell, J. T. Gorman, and S. T. Garnett. 2007. Investing in indigenous natural resource management. Charles Darwin University Press, Darwin, Australia.

Lutschini, M. 2005. Engaging with holism in Australian Aboriginal health policy - a review. Australia and New Zealand Health Policy 2(1):15. http://dx.doi.org/10.1186/1743-8462-2-15

Maller, C., M. Townsend, L. St Leger, C. Henderson-Wilson, A. Pryor, L. Prosser, and M. Moore. 2008. Healthy parks, healthy people: the health benefits of contact with nature in a park context. Second edition. Deakin University and Parks Australia, Melbourne, Australia. [online] URL: https://www.deakin.edu.au/ _data/assets/pdf_file/0016/310750/HPHP-2nd-Edition.pdf

Maller, C., M. Townsend, L. St Leger, C. Henderson-Wilson, A. Pryor, L. Prosser, and M. Moore. 2009. Healthy parks, healthy people: the health benefits of contact with nature in a park context. George Wright Forum 26(2):51-83.
Marika, B., B. Munyarryun, B. Munyarryun, N. Marawili, W. Marika, and S. Kerins. 2012. Ranger djama? Manymak! Pages 132-145 in J. Altman and S. Kerins, editors. People on country: vital landscapes, indigenous futures. Federation Press, Sydney, Australia.

Marika, M., and S. Roeger. 2012. Dhimurru wind bringing change. Pages 119-131 in J. Altman and S. Kerins, editors. People on country: vital landscapes, indigenous futures. Federation Press, Sydney, Australia.

Marston, A. 2013. Justice for all? Material and semiotic impacts of Fair Trade craft certification. Geoforum 44:162-169. http://dx. doi.org/10.1016/j.geoforum.2012.09.013

Mayrhofer, J., and J. Gupta. 2016. The politics of co-benefits in India's energy sector. Environment and Planning C: Politics and Space 34(7):1344-1363. http://dx.doi.org/10.1177/0263774x15619629

McAfee, K., and E. N. Shapiro. 2010. Payments for ecosystem services in Mexico: nature, neoliberalism, social movements, and the state. Annals of the Association of American Geographers 100 (3):579-599. http://dx.doi.org/10.1080/00045601003794833

McClenachan, L., S. Lovell, and C. Keaveney. 2015. Social benefits of restoring historical ecosystems and fisheries: alewives in Maine. Ecology and Society 20(2):31. http://dx.doi. org/10.5751/es-07585-200231

McDermott, C. L., L. Coad, A. Helfgott, and H. Schroeder. 2012. Operationalizing social safeguards in REDD+: actors, interests and ideas. Environmental Science and Policy 21:63-72. http://dx. doi.org/10.1016/j.envsci.2012.02.007

McDermott, R., K. O’Dea, K. Rowley, S. Knight, and P. Burgess. 1998. Beneficial impact of the Homelands Movement on health outcomes in central Australian Aborigines. Australian and New Zealand Journal of Public Health 22(6):653-658. http://dx.doi. org/10.1111/j.1467-842X.1998.tb01464.X

Meehan, B. 1982. Shell bed to shell midden. Australian Institute Of Aboriginal Studies, Canberra, Australia.

Morice, R. D. 1976. Woman dancing dreaming: psychosocial benefits of the Aboriginal outstation movement. Medical Journal of Australia 2(25-26):939-942.

Morphy, H. 1995. Landscape and the reproduction of the ancestral past. Pages 184-209 in E. Hirsch and M. O'Hanlon, editors. The anthropology of landscape: perspectives on place and space. Clarendon Press, Oxford, UK.

Morphy, H. 1998. Aboriginal art. Phaidon, London, UK.

Morrison, J. 2007. Caring for country. Pages 249-261 in J. C. Altman and M. Hinkson, editors. Coercive reconciliation: stabilise, normalise, exit Aboriginal Australia. Arena Publications Association, Melbourne, Australia.

Muller, S. 2008. Indigenous payment for environmental service (PES) opportunities in the Northern Territory: negotiating with customs. Australian Geographer 39(2):149-170. http://dx.doi. org/10.1080/00049180802056831

Myers, F. R. 1991. Pintupi country, Pintupi self: sentiment, place and politics among Western Desert Aborigines. University of California Press, Berkeley, California, USA. 
Nadasdy, P. 2003. Hunters and bureaucrats: power, knowledge, and Aboriginal-State relations in the southwest Yukon. UBC Press, Vancouver, Canada.

Netbalance Foundation. 2013. Benefiting from co-benefits in Australia. Netbalance Foundation, Melbourne, Australia. [online] URL: http://www.netbalance.com.au/s/CoBenefits Report. pdf

O’Dea, K. 1984. Marked improvement in carbohydrate and lipid metabolism in diabetic Australian Aborigines after temporary reversion to traditional lifestyle. Diabetes 33(6):596-603. http:// dx.doi.org/10.2337/diab.33.6.596

O’Dea, K., N. G. White, and A. J. Sinclair. 1988. An investigation of nutrition-related risk factors in an isolated Aboriginal community in northern Australia: advantages of a traditionallyorientated life-style. Medical Journal of Australia 148(4):177-180.

Olsen, K. H. 2007. The clean development mechanism's contribution to sustainable development: a review of the literature. Climatic Change 84(1):59-73. http://dx.doi.org/10.1007/ $\underline{\text { s10584-007-9267-y }}$

Pattanayak, S. K., S. Wunder, and P. J. Ferraro. 2010. Show me the money: Do payments supply ecosystem services in developing countries? Review of Environmental Economics and Policy 4 (2):254-274. https://doi.org/10.1093/reep/req006

Peacock, J., R. Hine, and J. Pretty. 2007. The mental health benefits of green exercise activities and green care. Mind Week Report. Centre for Environment and Society, University of Essex, Wivenhoe Park, UK. [online] URL: https://psyk-info. regionsyddanmark.dk/dwn109161.pdf

Petticrew, M., and H. Roberts. 2006. Systematic reviews in the social sciences: a practical guide. Blackwell, London, UK.

Pew Charitable Trusts. 2015. Working for our country: A review of the economic and social benefits of Indigenous land and sea management. Pew Charitable Trusts and Synergies Economic Consulting, Melbourne, Australia. [online] URL: http://www. pewtrusts.org/ /media/post-launch-images/2015/11/ economicandsocialbenefitsindigenouslandwhitepaper.pdf

Phelps, J., E. L. Webb, and A. Agrawal. 2010. Does REDD+ threaten to recentralize forest governance? Science 328:312-313. http://dx.doi.org/10.1126/science.1187774

Prout, S. 2012. Indigenous wellbeing frameworks in Australia and the quest for quantification. Social Indicators Research 109 (2):317-336. http://dx.doi.org/10.1007/s11205-011-9905-7

Pugalis, L. 2013. Hitting the target but missing the point: the case of area-based regeneration. Community Development 44 (5):617-634. http://dx.doi.org/10.1080/15575330.2013.854257

Putnis, A., P. Josif, and E. Woodward. 2007. Healthy country, healthy people: supporting Indigenous engagement in the sustainable management of Northern Territory land and seas. CSIRO, Darwin, Australia.

Rea, N., and J. Messner. 2008. Constructing Aboriginal NRM livelihoods: Anmatyerr employment in water management. Rangeland Journal 30(1):85-93. http://dx.doi.org/10.1071/ $\underline{\text { RJ07044 }}$
Richmond, C., S. J. Elliott, R. Matthews, and B. Elliott. 2005. The political ecology of health: perceptions of environment, economy, health and well-being among 'Namgis First Nation. Health and Place 11(4):349-365. http://dx.doi.org/10.1016/j. healthplace.2004.04.003

Rigby, C. W., A. Rosen, H. L. Berry, and C. R. Hart. 2011. If the land's sick, we're sick: The impact of prolonged drought on the social and emotional well-being of Aboriginal communities in rural New South Wales. Australian Journal of Rural Health 19 (5):249-254. http://dx.doi.org/10.1111/j.1440-1584.2011.01223.x

Robinson, C. J., G. James, and P. J. Whitehead. 2016. Negotiating Indigenous benefits from payment for ecosystem service (PES) schemes. Global Environmental Change 38:21-29. http://dx.doi. org/10.1016/j.gloenvcha.2016.02.004

Rose, D. B. 2000. Dingo makes us human: life and land in an Australian Aboriginal culture. Cambridge University Press, Cambridge, UK.

Rouja, P. M., É. Dewailly, C. Blanchet, and the Bardi Community. 2003. Fat, fishing patterns, and health among the Bardi people of North Western Australia. Lipids 38(4):399-405. http://dx.doi. org/10.1007/s11745-003-1075-Z

Rowley, K., A. Brown, K. Saraswati, R. Tilmouth, I. Roberts, J. Fitz, Z. Wang, R. McDermott, I. Anderson, D. Thomas, and K. O'Dea. 2006. Outstation is not a dirty word: lower than expected morbidity and mortality for an Aboriginal population. Northern Territory Chronic Disease Network: The Chronicle 9:5.

Rowley, K. G., K. O’Dea, I. Anderson, R. McDermott, K. Saraswati, R. Tilmouth, I. Roberts, J. Fitz, Z. Wang, A. Jenkins, J. D. Best, Z. Wang, and A. Brown. 2008. Lower than expected morbidity and mortality for an Australian Aboriginal population: 10-year follow-up in a decentralised community. Medical Journal of Australia 188(5):283-287. [online] URL: https://www.mja.com. au/system/files/issues/188_05_030308/row10886 fm.pdf

Russell-Smith, J., G. D. Cook, P. M. Cooke, A. C. Edwards, M. Lendrum, C. P. Meyer, and P. J. Whitehead. 2013. Managing fire regimes in north Australian savannas: applying Aboriginal approaches to contemporary global problems. Frontiers in Ecology and the Environment 11:e55-e63. http://dx.doi. org/10.1890/120251

Salafsky, N., and E. Wollenberg. 2000. Linking livelihoods and conservation: a conceptual framework and scale for assessing the integration of human needs and biodiversity. World Development 28(8):1421-1438. http://dx.doi.org/10.1016/S0305-750X(00)00031-0

Schwab, J. 2006. Kids, skidoos and caribou: The Junior Canadian Ranger program as a model for re-engaging Indigenous Australian youth in remote areas. CAEPR Discussion Paper 281/2006. Centre for Aboriginal Economic Policy Research, Canberra, Australia. [online] URL: http://caepr.anu.edu.au/sites/default/files/Publications/ DP/2006 DP281.pdf

Scrimgeour, D. 2007. Town or country: which is best for Australia's Indigenous peoples? Medical Journal of Australia 186 (10):532-533. [online] URL: https://www.mja.com.au/system/ files/issues/186_10_210507/scr10194_fm.pdf 
Sithole, B., H. Hunter-Xenie, L. Williams, J. Saegenschnitter, D. Yibarbuk, M. Ryan, O. Campion, B. Yunupingu, M. Liddy, E. Watts, C. Daniels, G. Daniels, P. Christophersen, V. Cubillo, E. Phillips, W. Marika, D. Jackson, and W. Barbour. 2008. Aboriginal land and sea management in the Top End: a community-driven evaluation. CSIRO Sustainable Ecosystems, Darwin, Australia. [online] URL: https://publications.csiro.au/rpr/download?pid= procite:fd86bcd3-a731-4e0d-8b8d-243742fac8a3\&dsid=DS1

Smyth, D. 2011. Indigenous land and sea management - a case study. Report prepared for the Australian Government Department of Sustainability, Environment, Water, Population and Communities on behalf of the State of the Environment 2011 Committee. DSEWPaC, Canberra, Australia. [online] URL: https://soe.environment.gov.au/file/51356

Social Health Reference Group. 2004. Social and emotional wellbeing framework: a national strategic framework for Aboriginal and Torres Strait Islander mental health and social and emotional well being 2004-2009. National Aboriginal and Torres Strait Islander Health Council and National Mental Health Working Group, Canberra, Australia. [online] URL: http://www.health. gov.au/internet/main/publishing.nsf/content/8E8CE65B4FD36C6DCA25722B008342B9/\$File/wellbeing.pdf

Social Ventures Australia. 2016. Consolidated report on Indigenous Protected Areas following social return on investment analyses. Social Ventures Australia and Department of Prime Minister and Cabinet, Canberra, Australia. [online] URL: http://www. $\underline{\text { socialventures.com.au/assets/Consolidated-SROI-Report-on-IPA- }}$ $\underline{\text { WoC.pdf }}$

Sommer, R., F. Learey, J. Summit, and M. Tirrell. 1994. The social benefits of resident involvement in tree planting. Journal of Arboriculture 20(6):170-175.

Stacey, N., A. Izurieta, and S. T. Garnett. 2013. Collaborative measurement of performance of jointly managed protected areas in northern Australia. Ecology and Society 18(1):19. http://dx.doi. org/10.5751/es-05273-180119

Stevens, S., editor. 2014. Indigenous peoples, national parks, and protected areas: a new paradigm linking conservation, culture, and rights. University of Arizona Press, Tucson, Arizona, USA.

Strang, V. 1997. Uncommon ground: cultural landscapes and environmental values. Berg, Oxford, UK.

Strang, V. 2008. Cosmopolitan natures: paradigms and politics in Australian environmental management. Nature and Culture 3 (1):41-62. http://dx.doi.org/10.3167/nc.2008.030104

Sutter, C. 2003. Sustainability check-up for CDM projects: how to assess the sustainability of international projects under they Kyoto Protocol. Wissenschaftlicher Verlag, Berlin, Germany.

Sutter, C., and J. C. Parreño. 2007. Does the current Clean Development Mechanism (CDM) deliver its sustainable development claim? An analysis of officially registered CDM projects. Climatic Change 84(1):75-90. http://dx.doi.org/10.1007/ s10584-007-9269-9

Thompson, S. L., R. D. Chenhall, and J. K. Brimblecombe. 2013. Indigenous perspectives on active living in remote Australia: a qualitative exploration of the socio-cultural link between health, the environment and economics. BMC Public Health 13:473. http://dx.doi.org/10.1186/1471-2458-13-473

Urbis. 2012. Assessment of the social outcomes of the Working on Country program. Urbis, Sydney, Australia. [online] URL: https:// www.environment.gov.au/indigenous/workingoncountry/publications/ woc-social.html

Vatn, A. 2010. An institutional analysis of payments for environmental services. Ecological Economics 69(6):1245-1252. http://dx.doi.org/10.1016/j.ecolecon.2009.11.018

Visseren-Hamakers, I. J., C. McDermott, M. J. Vijge, and B. Cashore. 2012. Trade-offs, co-benefits and safeguards: current debates on the breadth of REDD+. Current Opinion in Environmental Sustainability 4(6):646-653. http://dx.doi.org/10.1016/ j.cosust.2012.10.005

Watson, N. L. 2007. Implications of land rights reform for Indigenous health. Medical Journal of Australia 186(10):534-536. [online] URL: https://www.mja.com.au/system/files/issues/186_10_210507/ wat 10483 fm.pdf

Watts, N., W. N. Adger, P. Agnolucci, J. Blackstock, P. Byass, W. Cai, S. Chaytor, T. Colbourn, M. Collins, A. Cooper, P. M. Cox, J. Depledge, P. Drummond, P. Ekins, V. Galaz, D. Grace, H. Graham, M. Grubb, A. Haines, I. Hamilton, A. Hunter, X. Jiang, M. Li, I. Kelman, L. Liang, M. Lott, R. Lowe, Y. Luo, G. Mace, M. Maslin, M. Nilsson, T. Oreszczyn, S. Pye, T. Quinn, M. Svensdotter, S. Venevsky, K. Warner, B. Xu, J. Yang, Y. Yin, C. Yu, Q. Zhang, P. Gong, H. Montgomery, and A. Costello. 2015. Health and climate change: policy responses to protect public health. Lancet 386(10006):1861-1914. http://dx.doi.org/10.1016/ s0140-6736(15)60854-6

Weir, J. K. 2009. Murray River country: an ecological dialogue with traditional owners. Aboriginal Studies Press, Canberra, Australia.

Weir, J. K., C. Stacey, and K. Youngetob. 2011. The benefits associated with Caring for Country: literature review. Australian Institute of Aboriginal and Torres Strait Islander Studies, Canberra, Australia. [online] URL: https://www.environment. gov.au/indigenous/workingoncountry/publications/benefits-cfc.html

West, P., J. Igoe, and D. Brockington. 2006. Parks and peoples: the social impact of protected areas. Annual Review of Anthropology 35:251-277. http://dx.doi.org/10.1146/annurev. anthro.35.081705.123308

Westphal, L. M. 2003. Urban greening and social benefits: a study of empowerment outcomes. Journal of Arboriculture 29:137-147.

Wettenhall, G. 2014. Yirralka Rangers: putting both ways culture into practice. em PRESS Publishing, Victoria, Australia. [online] URL: http://www.empresspublishing.com.au/uploads/4/2/8/2/4282966/ yirralka rangers booklet link.pdf

Williams, N. M. 1986. The Yolngu and their land: a system of land tenure and the fight for its recognition. Stanford University Press, Stanford, California, USA.

Willis, E., M. Pearce, and T. Jenkin. 2004. The demise of the Murray River: insights into lifestyle, health and well-being for rural Aboriginal people in the riverland. Health Sociology Review 13(2):187-197. http://dx.doi.org/10.5172/hesr.13.2.187 
Willox, A. C., S. L. Harper, J. D. Ford, K. Landman, K. Houle, V. L. Edge, and Rigolet Inuit Community Government. 2012. "From this place and of this place:" climate change, sense of place, and health in Nunatsiavut, Canada. Social Sciences and Medicine 75(3):538-547. http://dx.doi.org/10.1016/j.socscimed.2012.03.043

Wilson, G. R., M. J. Edwards, and J. K. Smits. 2010. Support for Indigenous wildlife management in Australia to enable sustainable use. Wildlife Research 37(3):255-263. http://dx.doi. org/10.1071/WR09130

Wilson, K. 2003. Therapeutic landscapes and First Nations peoples: an exploration of culture, health and place. Health and Place 9(2):83-93. http://dx.doi.org/10.1016/s1353-8292(02)00016-3

Wilson, K., and M. W. Rosenberg. 2002. Exploring the determinants of health for First Nations peoples in Canada: Can existing frameworks accommodate traditional activities? Social Science and Medicine 55(11):2017-2031. http://dx.doi.org/10.1016/ $\underline{\mathrm{S} 0277-9536(01) 00342-2}$

Winer, M., H. Murphy, and H. Ludwick. 2012. Payment for ecosystem services markets on Aboriginal land in Cape York Peninsula: potential and constraints. United Nations Research Institute for Social Development, Geneva, Switzerland. [online] URL: http://www.unrisd.org/unrisd/website/document. nsf/(httpPublications)/27529D10F92E00DFC12579F200553BAF? OpenDocument

World Health Organization. 1948. Preamble to the Constitution of the World Health Organization as adopted by the International Health Conference, New York, 19-22 June, 1946; signed on 22 July 1946 by the representatives of 61 States (Official Records of the World Health Organization, no. 2, p. 100) and entered into force on 7 April 1948. World Health Organization, Geneva, Switzerland.

Yanner, M. 2008. Traditional owner comment. Native Title Newsletter 2008(4):4-6. [online] URL: http://aiatsis.gov.au/ publications/products/native-title-newsletter-july-2008

Young, E., H. Ross, J. Johnson, and J. Kesteven. 1991. Caring for country: Aborigines and land management. Australian National Parks and Wildlife Service, Canberra, Australia.

Zander, K. K. 2013. Understanding public support for indigenous natural resource management in northern Australia. Ecology and Society 18(1):11. http://dx.doi.org/10.5751/es-05267-180111

Zander, K. K., and S. T. Garnett. 2011. The economic value of environmental services on indigenous-held lands in Australia. PLoS One 6:e23154. http://dx.doi.org/10.1371/journal.pone.0023154 